People in Organisations 
Title of related interest

R. S. Giles and J. W. Capel, Finance and Accounting 


\title{
PEOPLE IN ORGANISATIONS
}

Edward Sallis

\author{
and \\ Kate Sallis
}

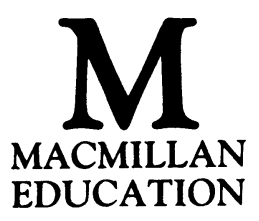


(C) Edward Sallis and Kate Sallis 1988

All rights reserved. No reproduction, copy or transmission of this publication may be made without written permission.

No paragraph of this publication may be reproduced, copied or transmitted save with written permission or in accordance with the provisions of the Copyright Act 1956 (as amended), or under the terms of any licence permitting limited copying issued by the Copyright Licensing Agency, 33-4 Alfred Place, London WC1E 7DP.

Any person who does any unauthorised act in relation to this publication may be liable to criminal prosecution and civil claims for damages.

First published 1988

Published by

MACMILLAN EDUCATION LTD

Houndmills, Basingstoke, Hampshire RG21 2XS

and London

Companies and representatives

throughout the world

British Library Cataloguing in Publication Data

Sallis, Edward

People in organisations.

1. Organization

I. Title II. Sallis, Kate

302.3'5'024658 HM131

ISBN 978-1-349-09230-7 ISBN 978-1-349-09228-4 (eBook)

DOI 10.1007/978-1-349-09228-4 


\section{Contents}

Acknowledgements

xi

Introduction

xii

$\begin{array}{ll}\text { SECTION I: STUDY } & 1\end{array}$

1 How to Study 3

Having a goal $\quad 3$

Activity: 'What are your goals?'

Study - the preliminary steps $\quad 5$

$\begin{array}{ll}\text { The diary method of learning } & 8\end{array}$

$\begin{array}{ll}\text { Making effective notes } & 8\end{array}$

2 Thinking and Creativity 12

$\begin{array}{ll}\text { Critical and creative thinking } & 13\end{array}$

$\begin{array}{ll}\text { Brainstorming } & 14\end{array}$

$\begin{array}{ll}\text { Key words } & 15\end{array}$

3 Managing your Time $\quad 17$

$\begin{array}{ll}\text { Logging your time } & 18\end{array}$

Activity: 'A time log' 20

$\begin{array}{ll}\text { Negotiation on work schedules } & 20\end{array}$

$\begin{array}{ll}\text { Priorities and objectives } & 20\end{array}$

SECTION II: COMMUNICATION 23

4 What is Communication? 25

Analysing communication - the theory 25

$\begin{array}{ll}\text { Communication barriers } & 28\end{array}$

Oral communications $\quad 29$

Qualities of speech $\quad 31$

Listening $\quad 33$

Improving listening skills $\quad 34$ 
5 The Business Letter $\quad 36$

$\begin{array}{ll}\text { What are business letters for? } & 37\end{array}$

$\begin{array}{ll}\text { Corporate identity and logos } & 37\end{array}$

Activity: 'Logos' $\quad 38$

$\begin{array}{ll}\text { Statutory requirements } & 38\end{array}$

Other essential information and stationery style $\quad 39$

How to lay out a business letter $\quad 40$

Writing the letter $\quad 46$

$\begin{array}{ll}\text { Tone and style } & 48\end{array}$

Standard letters and paragraphs $\quad 49$

Activity: 'Letter writing' 49

6 The Memorandum $\quad 51$

$\begin{array}{ll}\text { The format of the memo } & 51\end{array}$

What are memos used for? $\quad 53$

$\begin{array}{ll}\text { Style } & 53\end{array}$

Activity: 'Writing memos' $\quad 54$

7 Using the Telephone $\quad 56$

Activity: 'Smiling voices' $\quad 57$

$\begin{array}{ll}\text { Receiving calls } & 57\end{array}$

$\begin{array}{ll}\text { Making calls } & 58\end{array}$

8 Report Writing $\quad 60$

$\begin{array}{ll}\text { Types of report } & 60\end{array}$

$\begin{array}{ll}\text { Writing a report } & 61\end{array}$

$\begin{array}{ll}\text { Structure of reports } & 63\end{array}$

Activity: 'Report writing' $\quad 63$

9 Press Releases $\quad 64$

$\begin{array}{ll}\text { Writing a press release } & 64\end{array}$

$\begin{array}{ll}\text { Activity: 'Designing a press release' } & 66\end{array}$

10 Visual Presentation of Information $\quad 67$

$\begin{array}{ll}\text { Thinking in pictures } & 68\end{array}$

$\begin{array}{ll}\text { Varieties of presentation } & 69\end{array}$

$\begin{array}{ll}\text { Bar charts } & 69\end{array}$

$\begin{array}{ll}\text { Line graphs } & 72\end{array}$

$\begin{array}{ll}\text { Combined bar and line graph } & 75\end{array}$

$\begin{array}{ll}\text { Pie charts } & 75\end{array}$

$\begin{array}{ll}\text { Bubble charts } & 77\end{array}$

Activity: 'Bubble Charts Analysis' $\quad 78$

$\begin{array}{ll}\text { Pictograms } & 78\end{array}$ 
11 Giving a Talk $\quad 80$

$\begin{array}{lr}\text { Preparing for a talk } & 80\end{array}$

Activity: 'A talk' $\quad 82$

12 Communicating by Computer $\quad 84$

The language of computing $\quad 85$

Some computer essentials $\quad 86$

Activity: 'Word processing' $\quad 92$

Electronic communications $\quad 93$

$\begin{array}{ll}\text { Networking computers } & 94\end{array}$

13 Non-discriminatory Language $\quad 98$

Activity: 'Alternative titles' 100

$\begin{array}{lr}\text { SECTION III: ORGANISATIONS } & 103\end{array}$

14 The Structure of Organisations 105

How are organisations structured? 106

Activity: 'An organisation chart' 107

$\begin{array}{ll}\text { Organisational design } & 107\end{array}$

Activity: 'College structure' 110

Response to technological change -
mechanistic and organistic structures

Answers to 'organisation chart' activity $\quad 111$

Formal and informal organisations 112

15 Organisational Concepts $\quad 116$

$\begin{array}{ll}\text { Accountability } & 116\end{array}$

Activity: 'Accountability' $\quad 117$

$\begin{array}{ll}\text { Authority } & 118\end{array}$

Activity: 'Sources of authority' 119

$\begin{array}{ll}\text { Bureaucracy } & 119\end{array}$

Delegation $\quad 120$

$\begin{array}{ll}\text { Hierarchies } & 120\end{array}$

Management $\quad 122$

Management style $\quad 123$

$\begin{array}{ll}\text { Power } & 125\end{array}$

Responsibility $\quad 126$

Span of control $\quad 127$

$\begin{array}{ll}\text { Staff and line } & 127\end{array}$

Activity: 'College organisation chart' 128

$\begin{array}{ll}\text { Status } & 128\end{array}$

Answers to the 'sources of authority' activity 129 
16 Meetings 130

Types of meetings $\quad 131$

Committee meetings $\quad 132$

The 'hidden agenda' 134

Taking minutes 136

How to be successful at meetings 136

17 Information Systems $\quad 138$

$\begin{array}{ll}\text { Levels of information } & 139\end{array}$

$\begin{array}{ll}\text { Too much information } & 140\end{array}$

$\begin{array}{ll}\text { Why file? } & 140\end{array}$

$\begin{array}{ll}\text { Information sources } & 143\end{array}$

The impact of Information Technology 145

18 Management Services $\quad 147$

$\begin{array}{ll}\text { Methods of change } & 147\end{array}$

$\begin{array}{ll}\text { Managing by objectives } & 147\end{array}$

$\begin{array}{ll}\text { Organisation and Methods } & 149\end{array}$

The aims of Organisation and Methods $\quad 149$

How $O \& M$ is carried out $\quad 150$

19 Job Evaluation 154

Why should some jobs be worth more than others? 154

Activity: 'Job evaluation' 155

Methods of job evaluation $\quad 157$

$\begin{array}{ll}\text { Job ranking } & 158\end{array}$

Activity: 'Job ranking' 158

$\begin{array}{lr}\text { Paired comparisons } & 159\end{array}$

$\begin{array}{ll}\text { Analytical methods } & 159\end{array}$

Job evaluation procedure under points rating 161

Criticisms of job evaluation 162

$\begin{array}{ll}\text { SECTION IV: PEOPLE } & 165\end{array}$

$\begin{array}{lll}20 & \text { Groups } & 167\end{array}$

$\begin{array}{ll}\text { What is a group? } & 167\end{array}$

Activity: 'Group membership' $\quad 168$

$\begin{array}{ll}\text { Formal and informal groups } & 169\end{array}$

$\begin{array}{ll}\text { What are groups good at? } & 169\end{array}$

$\begin{array}{ll}\text { Group norms } & 170\end{array}$

Stages of group development 171

Features of an effective work group $\quad 172$

$\begin{array}{ll}\text { Behaviour in groups } & 173\end{array}$

$\begin{array}{ll}\text { Group roles } & 174\end{array}$

$\begin{array}{ll}\text { Interactions in groups } & 175\end{array}$ 
Quality circles

$\begin{array}{ll}\text { Activity: 'Analysing a work group' } & 178\end{array}$

21 Self-presentation $\quad 180$

$\begin{array}{ll}\text { Roles } & 181\end{array}$

How should I put my message across? 182

$\begin{array}{ll}\text { Yourself and others } & 183\end{array}$

$\begin{array}{ll}\text { Being assertive } & 185\end{array}$

Structuring arguments and persuading others 186

22 Motivation and Human Needs $\quad 190$

$\begin{array}{ll}\text { What is motivation? } & 191\end{array}$

$\begin{array}{ll}\text { Human needs } & 191\end{array}$

Activity: 'Motivation — a self-analysis' $\quad 191$

$\begin{array}{ll}\text { Personnel policy and human needs } & 193\end{array}$

Is money a motivator? 195

The hygiene/motivator theory 196

What should an interesting job contain? 197

Activity: 'Your own motivation' 198

$\begin{array}{ll}\text { Equity theory } & 198\end{array}$

Activity: 'Equity and motivation' 199

$\begin{array}{ll}\text { Expectations and motivation } & 199\end{array}$

$\begin{array}{ll}\text { Job satisfaction } & 200\end{array}$

23 The Employment Process $\quad 202$

The selection process - the employer's needs 202

$\begin{array}{ll}\text { Employee specification } & 203\end{array}$

Activity: 'Describe yourself — a self-appraisal exercise' 203

Human resource planning $\quad 204$

Where do I look for a job? 208

Application forms and CVs $\quad 210$

Activity: 'Analysis of Sheila's CV' 213

$\begin{array}{ll}\text { Activity: 'Letter of application' } & 218\end{array}$

$\begin{array}{ll}\text { Preparing for an interview } & 218\end{array}$

$\begin{array}{ll}\text { Types of interviews } & 220\end{array}$

Interview questions $\quad 223$

24 Performance Appraisal 226

Does every organisation have a form of staff appraisal? 226

$\begin{array}{ll}\text { The purpose of appraisal } & 227\end{array}$

Appraisal methods $\quad 229$

$\begin{array}{ll}\text { Self-appraisal } & 231\end{array}$

An appraisal interview checklist $\quad 231$

Activity: 'Preparing for the annual appraisal interview' 233 
25 Opportunities and Change 234

What business am I in? 234

Activity: 'Opportunities' 236

The problem of change $\quad 236$

How to recognise opportunities $\quad 237$

$\begin{array}{ll}\text { SWOTs } & 237\end{array}$

Activity: 'New ideas' 239

$\begin{array}{ll}\text { Career planning } & 239\end{array}$

Activity: 'Career planning' 241

SECTION V: ASSIGNMENTS $\quad 243$

1 Mapping the College's Structure 245

2 The Press Release $\quad 246$

3 Applying for a Job $\quad 249$

4 Facing up to Change 252

5 Systems Analysis $\quad 254$

$\begin{array}{ll}\text { Bibliography } & 257\end{array}$

$\begin{array}{lr}\text { Index } & 259\end{array}$ 


\section{Acknowledgements}

The Training Office at Guildford College of Technology performed sterling work in typing the manuscript and coping with our near illegible handwriting. The students and the Training Office Manager, Joy Bell, deserve our thanks. Without them there would be no book.

We could never have written this book without the help of the countless students we have taught over the years and who have provided the stimulus for our thinking. The experience of working in BTEC teams at Somerset College of Arts and Technology provided the initial motivation, and team teaching with Joyce Miles the inspiration for writing the book. Our colleagues at Guildford College of Technology, East Surrey College and Bracknell College have been a tremendous source of help and ideas. To all our colleagues past and present go our thanks.

Extracts from BS 3138: 1979 are reproduced by permission of BSI. Complete copies can be obtained from them at Linford Wood, Milton Keynes, MK14 6LE.

The quoted material on pages $162-163$ is reproduced with the permission of the Times Educational Supplement.

Guildford, 1987

Edward and Kate Sallis 


\section{Introduction}

Work is carried out by people in organisations. Hence the title of the new BTEC Unit for the National Level courses in Business and Finance, Distribution Studies, Public Administration, and Leisure Studies. 'People in Organisations' is also the theme as well as the title of this book. Its aim is to assist you explore the major activities which people do and which affect them at work. Examples of the type of questions which the book seeks to answer are;

'What makes us work?'

'What use can we make of information technology and how does it affect our working lives?'

'What exactly is a job and how is it best designed?'

'How can we make ourselves better at seeking jobs and planning our careers?'

'How is work best organised?'

'How can our success be measured?'

'How can we make ourselves better communicators?'

'How can we become more effective at work?'

'Are we sufficiently aware of the needs of others?'

In short, this book aims to help you to become a more effective member of an organisation. It is not all you will need. Your lecturers' notes and directions and the assignments you are given to perform are important complementary activities to those in this book. No textbook can do justice to every aspect of a syllabus. In this book we have sought to cover the important aspects of human resources in organisations as they affect students studying for BTEC awards, but we make no claims to be comprehensive in our coverage. The book is one of the many aids to learning and only a part of your total educational experience.

All of you have some experience of organisations to which you can relate. Those of you in employment or on Youth Training Schemes have your companies, while full-time students have their colleges and their work 
experience placements. Most of you are also members of other organisations and these can be useful when you need to make comparisons. Many of you are members of clubs, societies, and other organisations such as voluntary bodies and trade unions. In addition, during your course you will visit offices and factories and, of course, go shopping. Shopping and leisure visits to places like swimming pools, museums, concert halls, theatres and sports centres can provide interesting insights into how organisations work. How often have you been into a shop and said "this place is inefficient", or "this is my favourite shop - the assistants are always knowledgeable and friendly", or again "they really ought to improve the layout here, one cannot find anything." All of these are organisational judgements. What most of us usually do is to stop there and rarely ask why a particular place works well or gives a good service and another does not. If you are to build up your knowledge, you are going to require a framework to help you analyse how organisations operate.

You also need to know how organisations communicate with their customers and clients. You need to be interested in what sort of people they employ. In order for an organisation to function well a large number of complex factors come into play: finance, marketing, technology, competition, human resources, and it is the interplay of these forces that a BTEC course is about.

In addition, this book is concerned with PEOPLE and in particular $Y O U$. It is a well-worn cliché that an organisation is only as good as the people working in it, but it is nevertheless true. You will want to know how best to prepare yourself for working life, how to relate to others, and to discover what an organisation expects of you.

The authors have taught BTEC students at First, National, Higher National and Continuing Education levels, and as a result we know the demanding yet fascinating time which BTEC students can have on their course. We are committed to a student-centred approach to learning and we believe that you learn best by taking part in activities.

In order to promote this approach we have included a number of activities in this book. They are designed to help you develop your skills. They are not full-blown assignments although many could be readily adapted. We appreciate that most lecturers and course teams prefer to write their own material and rarely use many of the assignments provided in textbooks. The majority of the activities in this book have been designed for individual students to carry out in their own time to supplement assignment work. The exercises are designed to provide the impetus for deeper thought about the topic in question. A small number of full-scale assignments are included in Section V. 